\title{
Association of Continuous-Equivalent Urea Clearances with Death Risk in Intermittent Hemodialysis
}

\author{
Aarne Vartia, ${ }^{1}$ Heini Huhtala, ${ }^{2}$ and Jukka Mustonen ${ }^{3,4}$ \\ ${ }^{1}$ Savonlinna Central Hospital, 57120 Savonlinna, Finland \\ ${ }^{2}$ School of Health Sciences, University of Tampere, 33014 Tampere, Finland \\ ${ }^{3}$ School of Medicine, University of Tampere, 33014 Tampere, Finland \\ ${ }^{4}$ Tampere University Hospital, 33521 Tampere, Finland \\ Correspondence should be addressed to Aarne Vartia; aarne.vartia@gmail.com
}

Received 19 January 2016; Accepted 30 March 2016

Academic Editor: Deepak Malhotra

Copyright (C) 2016 Aarne Vartia et al. This is an open access article distributed under the Creative Commons Attribution License, which permits unrestricted use, distribution, and reproduction in any medium, provided the original work is properly cited.

Background. Several reports describe favorable results from frequent hemodialysis, but due to the lack of unequivocal dose measures it is not clear whether the benefits are due to more efficient toxin removal or other factors. Methods. The associations with death risk of six continuous-equivalent urea clearance measures were compared in 57 conventional in-center hemodialysis treatment periods of 51 patients, together 114 patient years. The double pool dose measures were calculated with the Solute-Solver program and separately scaled to urea distribution volume or normalized with body surface area. Results. Mortality associated significantly with equivalent renal urea clearance (EKR) scaled to urea distribution volume $(V)(p=0.033)$ and with EKR normalized with body surface area (BSA) $(p=0.044)$ but not with $V$-scaled $(p=0.059)$ nor BSA-normalized $(p=0.183)$ standard clearance (stdK). Women had significantly higher normalized protein catabolic rate (nPCR), EKR/ $V$, and stdK/ $V$ than men but slightly lower BSA-normalized dose measures and lower mortality. Protein catabolic rate and dialysis dose correlated positively with each other and with survival. Conclusions. The prognostically most valid continuous-equivalent clearance in the present material was $\mathrm{EKR} / V$, calculated from double pool urea generation rate, distribution volume, and time-averaged concentration.

\section{Introduction}

Survival correlates with urea-based hemodialysis session dose in many large registry studies (Lowrie et al. [1]: 43,334 patients, Port et al. [2]: 84,936 patients, and Miller et al. [3]: 88,153 patients) in conventional thrice-weekly schedule, but in the randomized controlled HEMO trial mean equilibrated $\mathrm{K} t / V(\mathrm{eK} t / V) 1.53$ did not result in a significantly better outcome than 1.16 [4].

Intermittent hemodialysis treatments can be compared to each other by the session dose measures URR, $\mathrm{K} t, \mathrm{~K} t / V$, and $e \mathrm{~K} t / V$ only if the treatment frequency is equal. Several observational studies, referred to in $[5,6]$, and the randomized controlled FHN trial [7] describe positive results from frequent ("daily") hemodialysis. However, the role of solute removal efficiency remains obscure.

Urea distribution volume $(V)$ is an essential variable in kinetic modeling and can be used as a representative of patient size, a scaling factor. However, it may have also an independent effect on outcome [1,8], which weakens the value of $\mathrm{K} t / V$ as a prognostic factor. BSA has recently been recommended for scaling of dialysis dose similarly as in expressing the glomerular filtration rate [9]. $V$-scaled dosing may result in suboptimal outcome in women and children.

Equivalent renal urea clearance (EKR, Casino and Lopez) [10] and standard clearance (stdK, Gotch) [11, 12] take treatment frequency and residual renal function (RRF) into account and they were intended for use in comparing dialysis doses in different schedules and for continuous dialysis and renal function $[13,14]$.

RRF may contribute significantly to the total weekly solute removal [14] but only minimally (usually $<1 \%$ ) to the delivered $\mathrm{K} t / V$ or URR measured from blood samples. Renal clearance $\left(\mathrm{K}_{\mathrm{r}}\right)$ can be added mathematically to session $\mathrm{K} t / \mathrm{V}$ [15-17]. Continuous-equivalent clearance based on UKM 
TABLE 1: Association of patient characteristics and dialysis dose measures with death risk in 57 hemodialysis treatment periods of 51 patients.

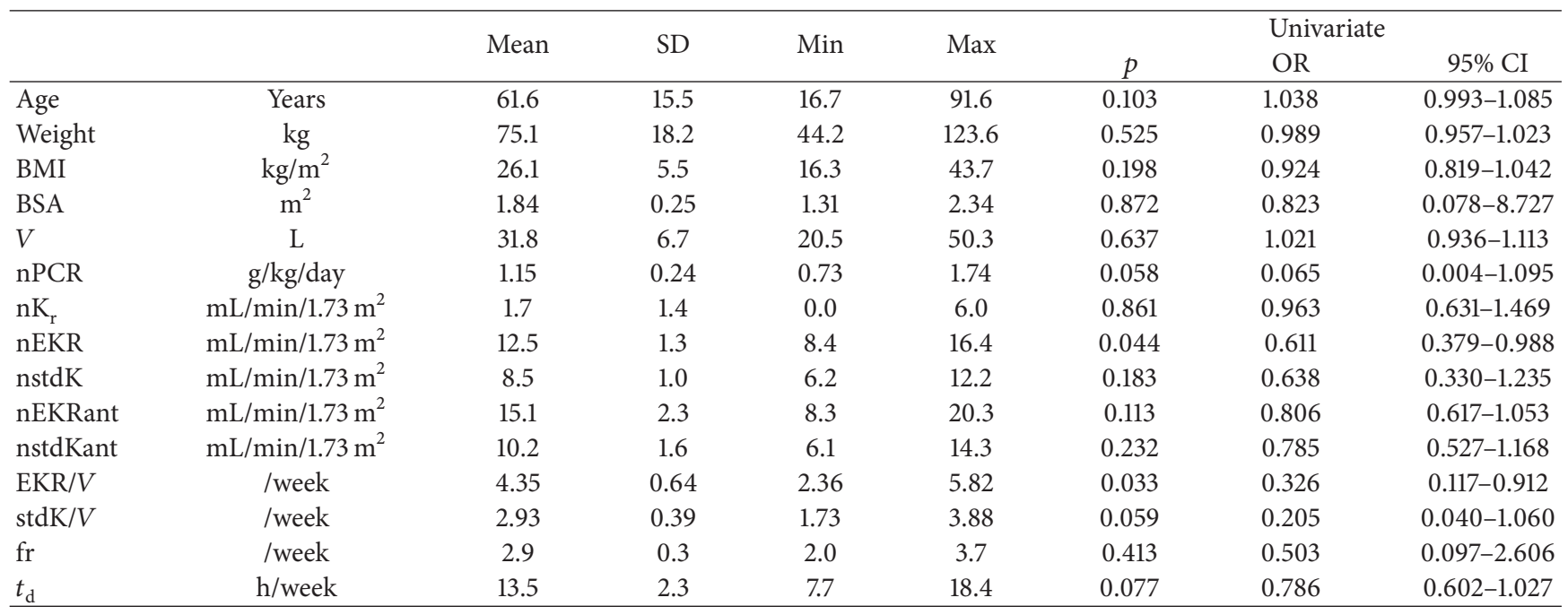

TABLE 2: Hemodialysis treatment period durations and reasons for discontinuation.

\begin{tabular}{lcccccc}
\hline & \multirow{2}{*}{$N$} & \multicolumn{4}{c}{ Duration (years) } \\
& & & Mean & SD & Min & Max \\
\hline Continuing & 19 & 33.3 & 2.5 & 1.7 & 0.4 & 5.8 \\
Death & 16 & 28.1 & 2.3 & 1.6 & 0.6 & 6.9 \\
Transplantation & 8 & 14.0 & 1.4 & 1.3 & 0.6 & 4.6 \\
Transfer to another unit & 8 & 14.0 & 1.3 & 1.2 & 0.3 & 3.8 \\
Transfer to peritoneal dialysis & 3 & 5.3 & 2.1 & 1.4 & 0.7 & 3.5 \\
Decision & 3 & 5.3 & 0.8 & 0.3 & 0.6 & 1.1 \\
\hline
\end{tabular}

The numbers include hemodialysis treatment periods ongoing on January 1,1998 (from that date on), and incident periods during the nine-year observation time until December 31, 2006 (unless terminated earlier).

includes $\mathrm{K}_{\mathrm{r}}$ automatically. Renal function is "qualitatively" better than dialysis with equal urea clearance [18].

In theory, the continuous-equivalent average clearance based on double pool UKM and including RRF is fine, but the best measure is the one most closely associated with outcome. Only few earlier reports correlate mortality directly with ECC [7,19-22]. The aim of the present preliminary study was to compare the prognostic value of different continuousequivalent urea clearances as dialysis dose measures.

\section{Subjects and Methods}

The study is a retrospective registry analysis from a hospital providing adult hemodialysis services in a district with a catchment area of some 50,000 inhabitants in Eastern Finland. The observation time was nine years, from January 1, 1998, to December 31, 2006. The material comprises 57 conventional in-center hemodialysis treatment periods of 51 patients, in total 114 patient years. Periods lasting under 90 days are not included. Patient characteristics are described in Table 1. Table 2 presents the characteristics of the dialysis treatment periods. "Decision" refers to a unanimous decision by patient and physician to discontinue renal replacement therapy.

Dosing of dialysis, including treatment frequency, was prescribed by the first author on multiple criteria (weight, hydration status, predialysis plasma urea concentration, and other laboratory values, eKt $/ V$ targets, and patient's preferences). Renal diagnosis, comorbidity, functional status, waiting for transplantation, age, anticipated survival time, and protein catabolic rate (PCR) were not used as dosing criteria. The patients were encouraged by a dietician to use a diet containing protein $1.2 \mathrm{~g} / \mathrm{kg} / \mathrm{day}$, but the actual dietary protein intake was not controlled.

Urea kinetic modeling with interdialysis urine collection was performed monthly. $\mathrm{K}_{\mathrm{r}}$ was interpolated from previous and next measurements if urine collection occasionally failed. RRF was detected in $68 \%$ of UKM sessions. In $15 \%$ of them, $\mathrm{K}_{\mathrm{r}}$ was interpolated. The numbers describing the patient characteristics and dialysis dose measures are means of each treatment period.

Double pool UKM calculations were conducted with the Solute-Solver program version 1.97 (July 2, 2010, with source code) [23], accessed November 12, 2015: http://www.ureakinetics.org/.

Dialyzer mass area coefficient $\left(\mathrm{K}_{0} A\right)$ reported by the dialyzer manufacturer is used in Solute-Solver in calculating dialyzer clearance $\left(\mathrm{K}_{\mathrm{d}}\right)$ from $\mathrm{Q}_{\mathrm{b}}$ and $\mathrm{Q}_{\mathrm{d}}$ with Michaels' equation [24].

Six double pool continuous-equivalent urea clearance measures were compared:

$$
\begin{aligned}
& \operatorname{EKR} / V \text { (/week). } \\
& \operatorname{nEKR~}\left(\mathrm{mL} / \mathrm{min} / 1.73 \mathrm{~m}^{2}\right) . \\
& \operatorname{nEKRant}\left(\mathrm{mL} / \mathrm{min} / 1.73 \mathrm{~m}^{2}\right) . \\
& \operatorname{stdK} / V \text { (/week). } \\
& \text { nstdK (mL/min } \left./ 1.73 \mathrm{~m}^{2}\right) . \\
& \text { nstdKant }\left(\mathrm{mL} / \min / 1.73 \mathrm{~m}^{2}\right) .
\end{aligned}
$$


TABLE 3: Dialysis treatment periods divided into two groups with approximately equal mean nPCR.

\begin{tabular}{|c|c|c|c|c|c|c|}
\hline & & & & & & \\
\hline & & & & & & $p$ value \\
\hline & & Mean & $\mathrm{SD}$ & Mean & $\mathrm{SD}$ & \\
\hline Age & Years & 60.8 & 13.2 & 62.5 & 17.7 & 0.668 \\
\hline Weight & $\mathrm{kg}$ & 77.1 & 21.2 & 72.9 & 14.7 & 0.393 \\
\hline BMI & $\mathrm{kg} / \mathrm{m}^{2}$ & 26.5 & 6.5 & 25.7 & 4.4 & 0.595 \\
\hline BSA & $\mathrm{m}^{2}$ & 1.86 & 0.27 & 1.81 & 0.22 & 0.441 \\
\hline$V$ & $\mathrm{~L}$ & 33.7 & 7.5 & 29.8 & 5.1 & 0.024 \\
\hline nPCR & $\mathrm{g} / \mathrm{kg} /$ day & 1.19 & 0.28 & 1.12 & 0.19 & 0.283 \\
\hline $\mathrm{nK}_{\mathrm{r}}$ & $\mathrm{mL} / \mathrm{min} / 1.73 \mathrm{~m}^{2}$ & 2.0 & 1.4 & 1.4 & 1.4 & 0.102 \\
\hline nEKR & $\mathrm{mL} / \mathrm{min} / 1.73 \mathrm{~m}^{2}$ & 12.1 & 1.5 & 13.0 & 1.0 & 0.005 \\
\hline nstdK & $\mathrm{mL} / \mathrm{min} / 1.73 \mathrm{~m}^{2}$ & 8.3 & 1.1 & 8.7 & 0.9 & 0.240 \\
\hline nEKRant & $\mathrm{mL} / \mathrm{min} / 1.73 \mathrm{~m}^{2}$ & 14.2 & 2.4 & 16.2 & 1.7 & 0.001 \\
\hline nstdKant & $\mathrm{mL} / \mathrm{min} / 1.73 \mathrm{~m}^{2}$ & 9.8 & 1.7 & 10.7 & 1.3 & 0.023 \\
\hline $\mathrm{EKR} / V$ & /week & 3.99 & 0.59 & 4.72 & 0.45 & $<0.001$ \\
\hline $\operatorname{stdK} / V$ & /week & 2.75 & 0.38 & 3.12 & 0.30 & $<0.001$ \\
\hline Treatment frequency & /week & 2.8 & 0.4 & 3.1 & 0.2 & 0.006 \\
\hline Treatment time & h/week & 12.6 & 2.5 & 14.4 & 1.7 & 0.003 \\
\hline Treatment periods & $n$ & 29 & & 28 & & \\
\hline Women & $\%$ & 31.0 & & 46.4 & & 0.233 \\
\hline Diabetics & $\%$ & 37.9 & & 46.4 & & 0.516 \\
\hline Ending with death & $\%$ & 37.9 & & 17.9 & & 0.092 \\
\hline Patient years & $n$ & 49.8 & & 64.5 & & \\
\hline Deaths & $n$ & 11 & & 5 & & \\
\hline Mortality & $/ 1000$ py & 221 & & 78 & & 0.049 \\
\hline
\end{tabular}

Their definitions are described in the Appendix. EKR is based on time-averaged urea concentration; stdK is based on average peak concentration. All include diffusion, convection, and renal clearance.

2.1. Statistical Methods. Continuous variables are expressed as means with standard deviations (SD) and minimum and maximum values. Categorical variables are expressed as percentages.

Univariate and multivariable binary logistic regression analyses were performed to identify variables associated with death. Variables with a univariate $p$ value $<0.10$ were entered into the multivariable models. Odds ratios (ORs) and 95\% confidence intervals (CIs) are reported.

Linear regression analysis was used to evaluate the interaction of dialysis dose and nPCR (Figure 1) and the material was split into two groups on the basis of EKR/ $V$ and $n P C R$ (Table 3).

SPSS 22.0 and STATA 13.1 were used in statistical calculations. The graph was drawn with Excel 2007.

\section{Results}

The overall mortality was 140 per 1,000 patient years. The main results are shown in Table 1. Mortality was significantly associated only with EKR/ $V$ and nEKR. In multivariable analysis, EKR/ $V$ was the only variable having an association with death risk $(\mathrm{OR}=0.326, \mathrm{CI}=0.117-0.912$, and $p=0.033)$.

Figure 1 illustrates the linear regression between nPCR and $\mathrm{EKR} / V$. To eliminate the confounding effect of $\mathrm{nPCR}$ on the dose-mortality relationship, the material was split into two groups with approximately equal mean nPCR but different mean EKR $/ V$. The line separating the groups is depicted in Figure 1. Table 3 shows that the difference in mortality between the low and high dose groups is still significant.

Men had lower nPCR, EKR/ $V$, and stdK/ $V$ and higher mortality than women (Table 4). Diabetics had higher weight, BMI, and BSA but did not differ significantly from nondiabetics in mortality (Table 5).

Correlations between some patient characteristics and continuous-equivalent clearances are shown in Table 6. All clearances correlate with each other.

\section{Discussion}

The association of six continuous-equivalent urea clearance measures with death risk was evaluated by statistical analysis. The most significant predictor in univariate analysis and the only significant one in multivariable analysis was $\mathrm{EKR} / V$, calculated from TAC ( $p=0.033)$. The $p$ value of $s t d K / V$ (from PAC) was 0.059 . In the old NCDS, TAC had a closer correlation with outcome than PAC [25]. The stdK concept is compliant with the peak concentration hypothesis [26], not supported by the present results.

Normalizing with BSA was tested by the variables nEKR and nstdK, with $\mathrm{mL} / \mathrm{min} / 1.73 \mathrm{~m}^{2}$ (or L/week $/ 1.73 \mathrm{~m}^{2}$ ) as their unit. nEKR was significantly associated with death risk, but nstdK was not. In the present study, $K_{d}$ was derived from $Q_{b}, Q_{d}$, and $K_{0} A$ reported by the dialyzer manufacturer. 
TABLE 4: Dialysis treatment periods by gender.

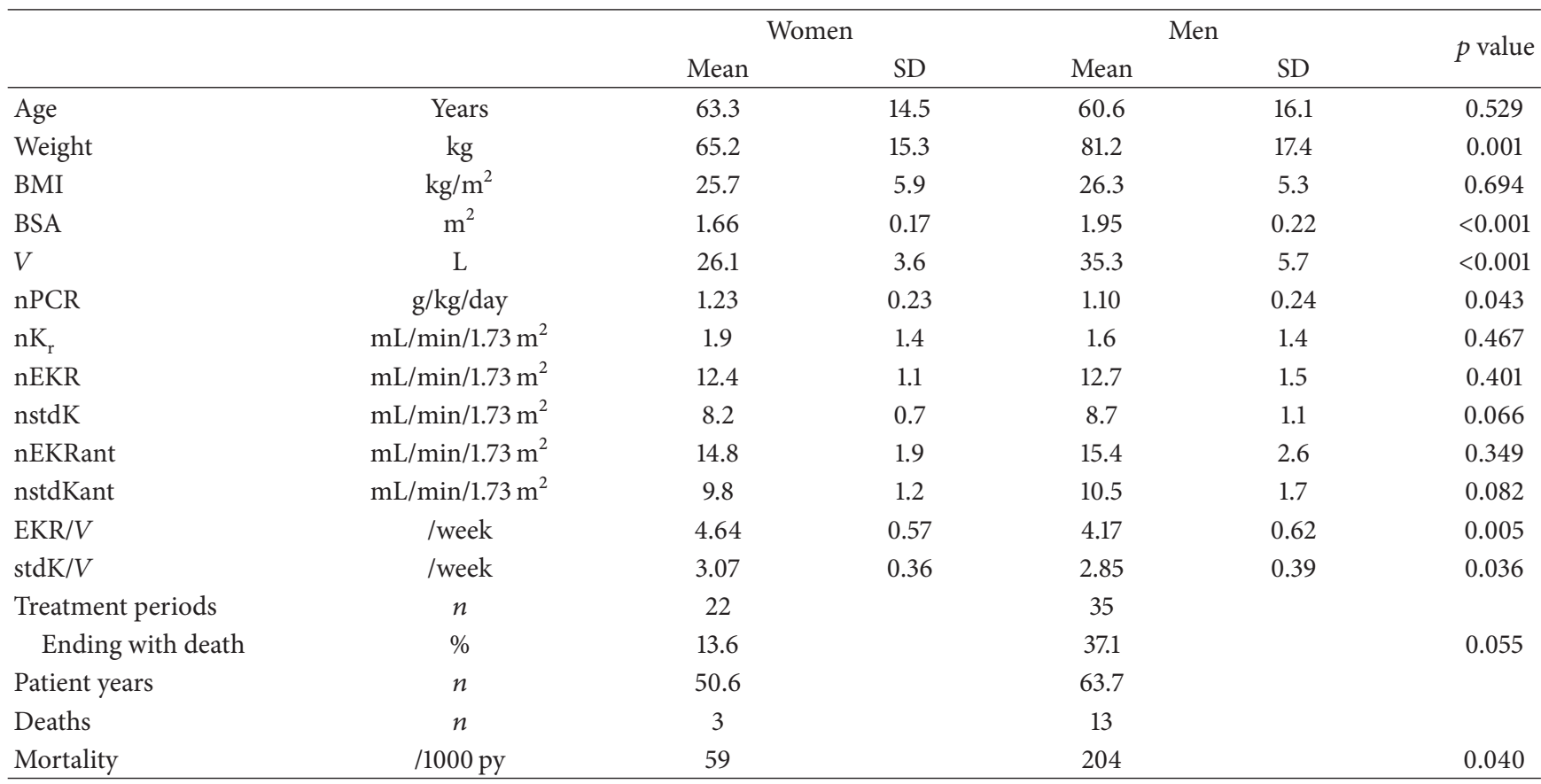

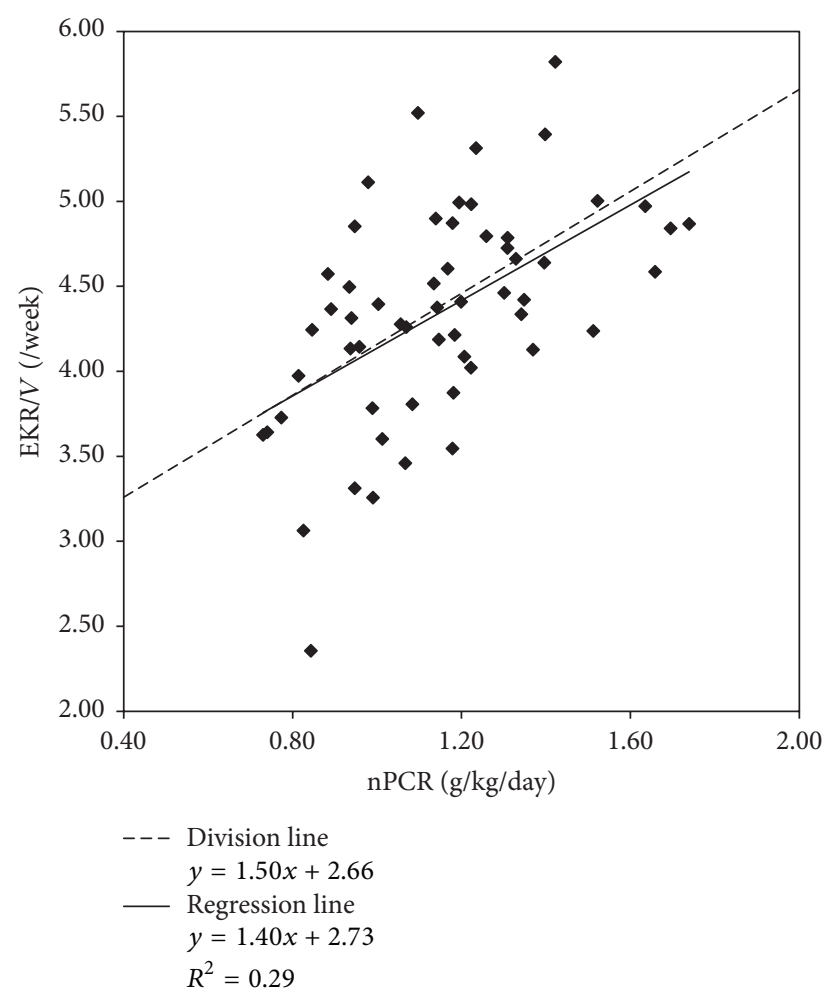

FIGURE 1: Linear regression between nPCR and dialysis dose $(\mathrm{EKR} / V)$ and the line separating the groups of Table 3.

Calculated with Michaels' equation [24], a 50\% error in $\mathrm{K}_{0} A$ causes an error of some $10 \%$ in $K_{d}$ with usual $Q_{b}$ and $Q_{d}$. Errors in $\mathrm{K}_{\mathrm{d}}$ cause in UKM proportional errors in $V$ and $G$.
In $\mathrm{EKR} / V$ and $\operatorname{stdK} / V$, the errors cancel each other out, but not in nEKR and nstdK.

Two other BSA-normalized continuous-equivalent clearances nEKRant and nstdKant were calculated applying the method of Daugirdas et al. described in the Appendix [9, 27]. The anthropometric total body water is usually larger compared to the kinetic $V$. Thus, nEKRant and nstdKant are higher than the simple BSA-normalized values. They are UKM-based continuous-equivalent hemodialysis dose measures, where the possible errors in $\mathrm{K}_{\mathrm{d}}$ are eliminated, normalized with two anthropometric measures of body size and with $\mathrm{mL} / \mathrm{min} / 1.73 \mathrm{~m}^{2}$ as unit. However, normalizing with BSA with either method did not improve the predictive value of EKR/ $V$ and $s t d K / V$.

In the HEMO trial, the age-adjusted mortality did not differ significantly between genders, but women did benefit from higher dose [28]. In the present study, women had lower mortality and got higher EKR/ $V$ and stdK/ $V$ but slightly lower BSA-normalized doses (Table 4). Comorbidity other than diabetes was not analyzed.

The rather wide range of dialysis doses in the present study is probably due to the opportunistic aspect: more may be better, but with large patients it is not easy to achieve a high dose (Table 6). In Table 3, the distribution volume and the proportion of men were higher in the low dose group. Men had higher mortality and volume and lower $V$-scaled dialysis dose (Table 4).

The patient characteristics and dialysis dose measures have multiple correlations or dependencies (Table 6). Figure 1 shows the linear regression between nPCR and EKR/ $V$. PCR is a function of $\mathrm{EKR} / V$ or $\operatorname{stdK} / V$ ((B.3) and (B.4) in Appendix). Thus, mathematical coupling is inevitable. It is also possible that nPCR depends on the dialysis dose 
TABLE 5: Dialysis treatment periods by diabetic status.

\begin{tabular}{|c|c|c|c|c|c|c|}
\hline & & & & & & \\
\hline & & & & & & $p$ value \\
\hline & & Mean & $\mathrm{SD}$ & Mean & $\mathrm{SD}$ & \\
\hline$\overline{\text { Age }}$ & Years & 61.2 & 14.9 & 62.0 & 16.1 & 0.842 \\
\hline Weight & $\mathrm{kg}$ & 81.7 & 18.5 & 70.2 & 16.7 & 0.018 \\
\hline BMI & $\mathrm{kg} / \mathrm{m}^{2}$ & 28.1 & 6.3 & 24.6 & 4.4 & 0.016 \\
\hline BSA & $\mathrm{m}^{2}$ & 1.92 & 0.22 & 1.78 & 0.25 & 0.037 \\
\hline$V$ & $\mathrm{~L}$ & 32.9 & 6.3 & 30.9 & 6.9 & 0.260 \\
\hline nPCR & $\mathrm{g} / \mathrm{kg} /$ day & 1.16 & 0.23 & 1.14 & 0.26 & 0.739 \\
\hline $\mathrm{nK}_{\mathrm{r}}$ & $\mathrm{mL} / \mathrm{min} / 1.73 \mathrm{~m}^{2}$ & 1.5 & 1.0 & 1.9 & 1.6 & 0.243 \\
\hline nEKR & $\mathrm{mL} / \mathrm{min} / 1.73 \mathrm{~m}^{2}$ & 12.7 & 0.9 & 12.4 & 1.6 & 0.356 \\
\hline nstdK & $\mathrm{mL} / \mathrm{min} / 1.73 \mathrm{~m}^{2}$ & 8.6 & 0.8 & 8.4 & 1.1 & 0.350 \\
\hline nEKRant & $\mathrm{mL} / \mathrm{min} / 1.73 \mathrm{~m}^{2}$ & 15.8 & 1.9 & 14.6 & 2.5 & 0.055 \\
\hline nstdKant & $\mathrm{mL} / \mathrm{min} / 1.73 \mathrm{~m}^{2}$ & 10.7 & 1.3 & 9.9 & 1.7 & 0.047 \\
\hline $\mathrm{EKR} / V$ & /week & 4.43 & 0.47 & 4.29 & 0.74 & 0.427 \\
\hline $\operatorname{stdK} / V$ & /week & 2.99 & 0.27 & 2.89 & 0.46 & 0.360 \\
\hline Treatment periods & $n$ & 24 & & 33 & & \\
\hline Ending with death & $\%$ & 25.0 & & 30.3 & & 0.660 \\
\hline Patient years & $n$ & 54.3 & & 60.0 & & \\
\hline Deaths & $n$ & 6 & & 10 & & \\
\hline Mortality & $/ 1000$ py & 110 & & 167 & & 0.439 \\
\hline
\end{tabular}

TABLE 6: Spearman's correlations, significant at the 0.01 level (2-tailed).

\begin{tabular}{lccccccccccc}
\hline & Weight & BMI & BSA & $V$ & nPCR & nEKR & nstdK & nEKRant & nstdKant & EKR/V & stdK/V \\
\hline Weight & 1 & 0.854 & 0.950 & 0.748 & & & 0.352 & 0.453 & 0.530 & \\
BMI & 0.854 & 1 & 0.658 & 0.455 & & & & 0.393 & 0.427 & \\
BSA & 0.950 & 0.658 & 1 & 0.817 & & & 0.364 & 0.430 & 0.521 & -0.475 & -0.354 \\
$V$ & 0.748 & 0.455 & 0.817 & 1 & & & 0.436 & & 0.493 & 0.519 & 0.535 \\
nPCR & & & & & 1 & & & 0.609 \\
nEKR & & & & & & 1 & 0.929 & 0.694 & 0.711 & 0.566 & 0.631 \\
nstdK & 0.352 & & 0.364 & 0.436 & & 0.929 & 1 & 0.569 & 0.686 & 0.351 & 0.509 \\
nEKRant & 0.453 & 0.393 & 0.430 & & 0.493 & 0.694 & 0.569 & 1 & 0.962 & 0.821 & 0.850 \\
nstdKant & 0.530 & 0.427 & 0.521 & & 0.519 & 0.711 & 0.686 & 0.962 & 1 & 0.706 & 0.809 \\
EKR/V & & & & -0.475 & 0.535 & 0.566 & 0.351 & 0.821 & 0.706 & 1 \\
stdK/V & & & & -0.354 & 0.609 & 0.631 & 0.509 & 0.850 & 0.809 & 0.961 \\
\hline
\end{tabular}

(causality) or that dosing of dialysis is guided by urea concentrations or adjusted for protein catabolic rate [29] as recommended by Gotch et al. [12, 30, 31] (reverse causality). All these factors may have a role in the present study, but their separate contribution could not be specified. In the HEMO trial, the effect of dose on nPCR and the role of mathematical coupling were estimated to be small [32].

PCR reflects dietary protein intake, which correlates with nutritional status and outcome [33]. In a recent large registry material mortality decreased with increasing nPCR until $1.3 \mathrm{~g} / \mathrm{kg} /$ day [34]. Table 3 shows that in the present study $\mathrm{EKR} / V$ had a significant association with mortality, although nPCR was slightly higher in the low EKR/ $V$ group. nPCR is associated with mortality directly and with the dialysis dose through the "fear of high urea concentrations" effectan example of the mechanisms possibly underlying the dosetargeting bias [35]. nPCR and dialysis dose may have a synergistic effect on survival.
A limitation of the present study is the small number of patients, which prevents robust conclusions. On the other hand, different dosing definitions were compared in the same material-a response to the challenge presented by Debowska et al. [36].

In summary, EKR/ $V$ and nEKR were significantly associated with mortality but stdK/ $V$ and nstdK were not. Normalizing with BSA $[9,37]$ did not improve the significance of the ECC measures.

\section{Appendix}

\section{A. Continuous-Equivalent Clearance (ECC)}

$\mathrm{EKR}\left(\mathrm{ECC}_{\mathrm{TA}}\right)$ and $\mathrm{stdK}\left(\mathrm{ECC}_{\mathrm{PA}}\right)$ are based on the definition of clearance $(\mathrm{K})$ :

$$
\mathrm{K}=\frac{E}{C}
$$


In steady state, the removal rate $(E)$ equals the generation rate $(G)$, and thus

$$
\mathrm{K}=\frac{G}{C} .
$$

In EKR, $C$ is the time-average concentration (TAC) and, in stdK, it is the average predialysis concentration (peak average concentration, PAC):

$$
\begin{aligned}
& \mathrm{EKR}=\frac{G}{\mathrm{TAC}}, \\
& \operatorname{stdK}=\frac{G}{\mathrm{PAC}} .
\end{aligned}
$$

The unit is, for example, $\mathrm{mL} / \mathrm{min}$ or $\mathrm{L} /$ week. Both may be scaled to body size by dividing by urea distribution volume $V$ and expressed as EKR/ $V$ and $\operatorname{stdK} / V$ :

$$
\begin{aligned}
& \mathrm{EKR} / V=\frac{\mathrm{EKR}}{V}, \\
& \operatorname{stdK} / V=\frac{\operatorname{stdK}}{V} .
\end{aligned}
$$

$G, V$, TAC, and PAC are determined by kinetic modeling, in the present study with Solute-Solver. TAC and PAC are whole-body water concentrations and $V$ is the postdialysis total volume $V_{t}$. The most practical unit of EKR/ $V$ and $\operatorname{stdK} / V$ is /week.

$\mathrm{nEKR}$ and nstdK are ECC values ( $\mathrm{ECC}_{\mathrm{TA}}$ and $\mathrm{ECC}_{\mathrm{PA}}$ ) normalized with body surface area analogically to glomerular filtration rate or renal clearance, with $\mathrm{mL} / \mathrm{min} / 1.73 \mathrm{~m}^{2}$ as the unit:

$$
\begin{aligned}
& \mathrm{nEKR}=\frac{\mathrm{EKR}}{\mathrm{BSA}} * 1.73, \\
& \mathrm{nstdK}=\frac{\operatorname{stdK}}{\mathrm{BSA}} * 1.73 .
\end{aligned}
$$

Daugirdas et al. have developed a method to get a BSAnormalized $\operatorname{stdK} t / V[9,27]$ :

$$
\mathrm{SAn}-\operatorname{stdK} t / V=\operatorname{stdK} t / V * \frac{\text { Vant }}{\mathrm{BSA} * 20},
$$

where Vant is anthropometric TBW in liters, BSA is in $\mathrm{m}^{2}$, and the constant 20 is the mean of $V / B S A\left(L / \mathrm{m}^{2}\right)$ in their material. Similarly, nEKRant and nstdKant can be calculated by using a combined anthropometric scaling factor Vant/BSA $(=\mathrm{TBW} / \mathrm{BSA})$ :

$$
\begin{aligned}
& \text { nEKRant }=\mathrm{EKR} / V * \frac{\text { Vant }}{\mathrm{BSA}} * 1.73, \\
& \text { nstdKant }=\operatorname{stdK} / V * \frac{\text { Vant }}{\mathrm{BSA}} * 1.73,
\end{aligned}
$$

with appropriate unit conversion factors. Vant/BSA takes gender into account. In the present material, its average value was $18.7(18.3-20.3) \mathrm{L} / \mathrm{m}^{2}$ for women and $21.9(20.2-$ 24.5) $\mathrm{L} / \mathrm{m}^{2}$ for men.

\section{B. nPCR}

By definition (see (A.4) and (A.6)),

$$
G=\operatorname{stdK} / V * \operatorname{PAC} * V .
$$

In hemodialysis, nPCR is generally calculated by the Borah equation [38] with Sargent's modification [39]:

$$
\mathrm{nPCR}=\frac{(9.35 * G+0.294 * V)}{(V / 0.58)},
$$

where $\mathrm{nPCR}$ is expressed in $\mathrm{g} / \mathrm{kg} / \mathrm{day}, G$ is expressed in milligrams of urea-N/min, and $V$ is expressed in L. By substituting $G$ from (B.1) and using appropriate unit conversion factors we get

$$
\mathrm{nPCR}=0.0151 * \operatorname{stdK} / V * \mathrm{PAC}+0.171,
$$

where $\mathrm{nPCR}$ is in $\mathrm{g} / \mathrm{kg} /$ day, stdK/ $V$ is in /week, and PAC is in $\mathrm{mmol} / \mathrm{L}$. $V$ will be eliminated. nPCR is high if concentration (PAC) is high despite high or normal clearance $(\operatorname{stdK} / V)$. stdK/ $V$ and PAC can be substituted with EKR/ $V$ and TAC:

$$
\mathrm{nPCR}=0.0151 * \mathrm{EKR} / V * \mathrm{TAC}+0.171
$$

$\mathrm{nPCR}$ is inevitably correlated with stdK/V and EKR/ $V$. The body surface area-normalized ECC measures are not so closely associated with nPCR.

\section{Abbreviations}

BMI: $\quad$ Body mass index $=$ weight $/$ height $^{2}$

BSA: $\quad$ Body surface area

$C: \quad$ Concentration

ECC: Continuous-equivalent clearance

EKR: $\quad$ Equivalent renal clearance $=G /$ TAC

EKR/ $V$ : EKR scaled to $V$

$\mathrm{eK} t / V: \quad$ Equilibrated $\mathrm{K} t / \mathrm{V}$

fr: Dialysis session frequency

$G$ : $\quad$ Generation rate

$\mathrm{K}_{\mathrm{d}}$ : $\quad$ Dialyzer clearance

$\mathrm{K}_{\mathrm{r}}$ : Renal clearance

$\mathrm{K}_{0} A: \quad$ Dialyzer mass area coefficient

$\mathrm{K} t: \quad$ Clearance $*$ session time

$\mathrm{K} t / V: \quad \mathrm{K} t$ scaled to distribution volume $=$ $\mathrm{K}_{\mathrm{d}} * t_{\mathrm{d}} / V_{t}$

nEKR: $\quad$ EKR normalized with BSA $\left(\mathrm{mL} / \mathrm{min} / 1.73 \mathrm{~m}^{2}\right)$

nEKRant: EKR normalized with BSA and Vant $\left(\mathrm{mL} / \mathrm{min} / 1.73 \mathrm{~m}^{2}\right)$

$\mathrm{nK}_{\mathrm{r}}: \quad \mathrm{K}_{\mathrm{r}}$ normalized with BSA $\left(\mathrm{mL} / \mathrm{min} / 1.73 \mathrm{~m}^{2}\right)$

nstdK: $\quad$ stdK normalized with BSA $\left(\mathrm{mL} / \mathrm{min} / 1.73 \mathrm{~m}^{2}\right)$

nstdKant: stdK normalized with BSA and Vant $\left(\mathrm{mL} / \mathrm{min} / 1.73 \mathrm{~m}^{2}\right)$

nPCR: $\quad$ PCR scaled to normal body weight $=$ $\mathrm{PCR} /(V / 0.58)$ (g/kg/day) 
PAC: Average predialysis concentration, peak average concentration

PCR: Protein catabolic rate (g/day)

py: $\quad$ Patient years

$Q_{b}$ : Dialyzer blood flow

$Q_{d}$ : Dialysate flow

RRF: Residual renal function

spK $t / V$ : Single pool Kt/V

stdK: $\quad$ Standard clearance $=G /$ PAC

stdK/V: stdK scaled to $V$

TAC: Time-averaged concentration

TBW: $\quad$ Total body water $($ Watson $)=$ Vant

$t_{\mathrm{d}}$ : Dialysis session duration

UF: Ultrafiltration volume (positive, if fluid is removed)

UKM: Urea kinetic model

$V: \quad$ Distribution volume

Vant: Anthropometric $V=\mathrm{TBW}$

$V_{t}: \quad$ Postdialysis $V$.

\section{Ethical Approval}

The study was based on an analysis of register data collected and utilized during the routine care of patients and conducted with the permission of the medical director of the hospital. There was no control group or randomization. The study was not presented to an ethics committee because there were no interventions and, according to Finnish law, registry reports are not subject to evaluation by ethics committees. The patient data were anonymized and deidentified prior to analysis.

\section{Competing Interests}

The authors declare that they have no competing interests.

\section{Acknowledgments}

The authors thank the team of the Dialysis Unit of Savonlinna Central Hospital for careful blood and urine sampling.

\section{References}

[1] E. G. Lowrie, Z. Li, N. Ofsthun, and J. M. Lazarus, "Body size, dialysis dose and death risk relationships among hemodialysis patients," Kidney International, vol. 62, no. 5, pp. 1891-1897, 2002.

[2] F. K. Port, R. A. Wolfe, T. E. Hulbert-Shearon, K. P. McCullough, V. B. Ashby, and P. J. Held, "High dialysis dose is associated with lower mortality among women but not among men," American Journal of Kidney Diseases, vol. 43, no. 6, pp. 1014-1023, 2004.

[3] J. E. Miller, C. P. Kovesdy, A. R. Nissenson et al., "Association of hemodialysis treatment time and dose with mortality and the role of race and sex," American Journal of Kidney Diseases, vol. 55, no. 1, pp. 100-112, 2010.

[4] G. Eknoyan, G. J. Beck, A. K. Cheung et al., "Effect of dialysis dose and membrane flux in maintenance hemodialysis," The New England Journal of Medicine, vol. 347, no. 25, pp. 2010-2019, 2002.
[5] R. M. Hakim and S. Saha, "Dialysis frequency versus dialysis time, that is the question," Kidney International, vol. 85, no. 5, pp. 1024-1029, 2014.

[6] E. Honkanen, I. Hazel, and D. Zimmerman, "High-dose hemodialysis: time for a change," Hemodialysis International, vol. 18, no. 1, pp. 3-6, 2014.

[7] The FHN Trial Group, "In-center hemodialysis six times per week versus three times per week," The New England Journal of Medicine, vol. 363, no. 24, pp. 2287-2300, 2010.

[8] E. G. Lowrie, Z. Li, N. Ofsthun, and J. M. Lazarus, "Measurement of dialyzer clearance, dialysis time, and body size: death risk relationships among patients," Kidney International, vol. 66, no. 5, pp. 2077-2084, 2004.

[9] J. T. Daugirdas, T. A. Depner, T. Greene et al., "Surface-areanormalized kt/v: a method of rescaling dialysis dose to body surface area-implications for different-size patients by gender," Seminars in Dialysis, vol. 21, no. 5, pp. 415-421, 2008.

[10] F. G. Casino and T. Lopez, "The equivalent renal urea clearance: a new parameter to assess dialysis dose," Nephrology Dialysis Transplantation, vol. 11, no. 8, pp. 1574-1581, 1996.

[11] F. A. Gotch, "The current place of urea kinetic modelling with respect to different dialysis modalities," Nephrology Dialysis Transplantation, vol. 13, supplement 6, pp. 10-14, 1998.

[12] F. A. Gotch, J. A. Sargent, and M. L. Keen, "Whither goest Kt/V?" Kidney International, vol. 58, supplement 76, pp. S3-S18, 2000.

[13] A. Vartia, "Effect of treatment frequency on haemodialysis dose: comparison of EKR and stdKtV," Nephrology Dialysis Transplantation, vol. 24, no. 9, pp. 2797-2803, 2009.

[14] A. Vartia, "Equivalent continuous clearances EKR and stdK in incremental haemodialysis," Nephrology Dialysis Transplantation, vol. 27, no. 2, pp. 777-784, 2012.

[15] S. Q. Lew, "How to measure residual renal function in patients on maintenance hemodialysis," Advances in Renal Replacement Therapy, vol. 1, no. 2, pp. 185-193, 1994.

[16] F. A. Gotch, "Kinetic modeling in hemodialysis," in Clinical Dialysis, A. R. Nissenson, R. N. Fine, and D. E. Gentile, Eds., pp. 156-188, Appleton \& Lange, Norwalk, Conn, USA, 3rd edition, 1995.

[17] National Kidney Foundation, "Clinical practice guidelines for hemodialysis adequacy, update 2006," American Journal of Kidney Diseases, vol. 48, supplement 1, pp. S2-S90, 2006.

[18] E. Vilar, D. Wellsted, S. M. Chandna, R. N. Greenwood, and K. Farrington, "Residual renal function improves outcome in incremental haemodialysis despite reduced dialysis dose," Nephrology Dialysis Transplantation, vol. 24, no. 8, pp. 25022510, 2009.

[19] M. Barreneche, R. Carreras, H. J. Leanza, and C. J. Najun Zarazaga, "The equivalent renal urea clearance and its relationship with mortality in chronic hemodlalysis patients," Medicina, vol. 59, no. 4, pp. 348-350, 1999.

[20] K. Manotham, K. Tiranathanagul, K. Praditpornsilpa, and S. Eiam-Ong, "Target quantity for twice-a-week hemodialysis: the EKR (equivalent renal urea clearance) approach," Journal of the Medical Association of Thailand, vol. 89, supplement 2, pp. S79S85, 2006.

[21] M. V. Rocco, R. S. Lockridge Jr., G. J. Beck et al., "The effects of frequent nocturnal home hemodialysis: the Frequent Hemodialysis Network Nocturnal Trial," Kidney International, vol. 80, no. 10, pp. 1080-1091, 2011. 
[22] R. Lockridge, G. Ting, and C. M. Kjellstrand, "Superior patient and technique survival with very high standard Kt/V in quotidian home hemodialysis," Hemodialysis International, vol. 16, no. 3, pp. 351-362, 2012.

[23] J. T. Daugirdas, T. A. Depner, T. Greene, and P. Silisteanu, "Solute-Solver: a web-based tool for modeling urea kinetics for a broad range of hemodialysis schedules in multiple patients," American Journal of Kidney Diseases, vol. 54, no. 5, pp. 798-809, 2009.

[24] J. T. Daugirdas and J. C. Van Stone, "Table A-1. Estimating dialyzer blood water clearance from KoA, Qb and Qd," in Handbook of Dialysis, J. T. Daugirdas, P. G. Blake, and T. S. Ing, Eds., p. 674, Lippincott Williams \& Wilkins, Philadelphia, Pa, USA, 3rd edition, 2001.

[25] N. M. Laird, C. S. Berkey, and E. G. Lowrie, "Modeling success or failure of dialysis therapy: the National Cooperative Dialysis Study," Kidney International, vol. 23, supplement 13, pp. S101S106, 1983.

[26] P. R. Keshaviah, K. D. Nolph, and J. C. Van Stone, “The peak concentration hypothesis: a urea kinetic approach to comparing the adequacy of continuous ambulatory peritoneal dialysis (CAPD) and hemodialysis," Peritoneal Dialysis International, vol. 9, no. 4, pp. 257-260, 1989.

[27] J. T. Daugirdas, T. Greene, G. M. Chertow, and T. A. Depner, "Can rescaling dose of dialysis to body surface area in the HEMO study explain the different responses to dose in women versus men?" Clinical Journal of the American Society of Nephrology, vol. 5, no. 9, pp. 1628-1636, 2010.

[28] T. Depner, J. Daugirdas, T. Greene et al., "Dialysis dose and the effect of gender and body size on outcome in the HEMO Study," Kidney International, vol. 65, no. 4, pp. 1386-1394, 2004.

[29] A. J. Vartia, "Adjusting hemodialysis dose for protein catabolic rate," Blood Purification, vol. 38, no. 1, pp. 62-67, 2014.

[30] F. A. Gotch and J. A. Sargent, "A mechanistic analysis of the National Cooperative Dialysis Study (NCDS)," Kidney International, vol. 28, no. 3, pp. 526-534, 1985.

[31] F. A. Gotch, "What is the role of Kt/V urea in chronic dialysis?" Seminars in Dialysis, vol. 3, pp. 74-75, 1990.

[32] M. V. Rocco, J. T. Dwyer, B. Larive et al., "The effect of dialysis dose and membrane flux on nutritional parameters in hemodialysis patients: results of the HEMO Study," Kidney International, vol. 65, no. 6, pp. 2321-2334, 2004.

[33] National Kidney Foundation, "K/DOQI clinical practice guidelines for nutrition in chronic renal failure," American Journal of Kidney Diseases, vol. 35, supplement 2, pp. S1-S140, 2000.

[34] V. A. Ravel, M. Z. Molnar, E. Streja et al., "Low protein nitrogen appearance as a surrogate of low dietary protein intake is associated with higher all-cause mortality in maintenance hemodialysis patients," Journal of Nutrition, vol. 143, no. 7, pp. 1084-1092, 2013.

[35] T. Greene, J. Daugirdas, T. Depner et al., "Association of achieved dialysis dose with mortality in the hemodialysis study: an example of 'dose-targeting bias,' Journal of the American Society of Nephrology, vol. 16, no. 11, pp. 3371-3380, 2005.

[36] M. Debowska, B. Lindholm, and J. Waniewski, "Kinetic modeling and adequacy of dialysis," in Progress in HemodialysisFrom Emergent Biotechnology to Clinical Practice, A. Carpi, C. Donadio, and G. Tramonti, Eds., chapter 1, pp. 3-26, InTech, Rijeka, Croatia, 2011.

[37] S. P. B. Ramirez, A. Kapke, F. K. Port et al., "Dialysis dose scaled to body surface area and size-adjusted, sex-specific patient mortality," Clinical Journal of the American Society of Nephrology, vol. 7, no. 12, pp. 1977-1987, 2012.

[38] M. F. Borah, P. Y. Schoenfeld, F. A. Gotch, J. A. Sargent, M. Wolfsen, and M. H. Humphreys, "Nitrogen balance during intermittent dialysis therapy of uremia," Kidney International, vol. 14, no. 5, pp. 491-500, 1978.

[39] J. A. Sargent, "Control of dialysis by a single-pool urea model: the National Cooperative Dialysis Study," Kidney International, vol. 23, supplement 13, pp. S19-S25, 1983. 


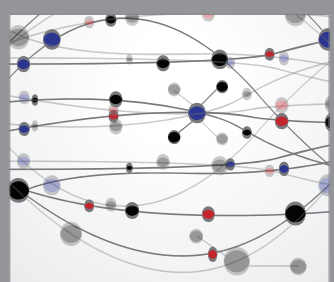

The Scientific World Journal
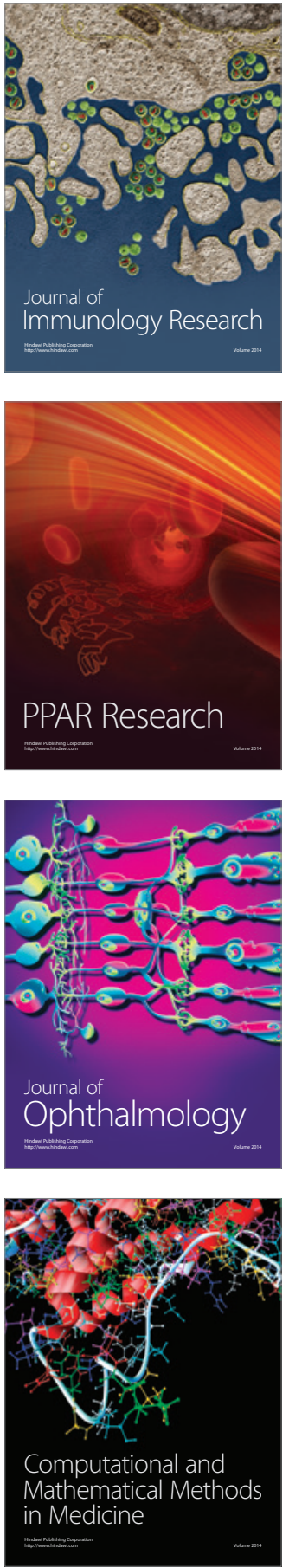

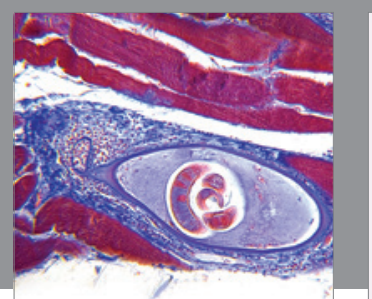

Gastroenterology Research and Practice

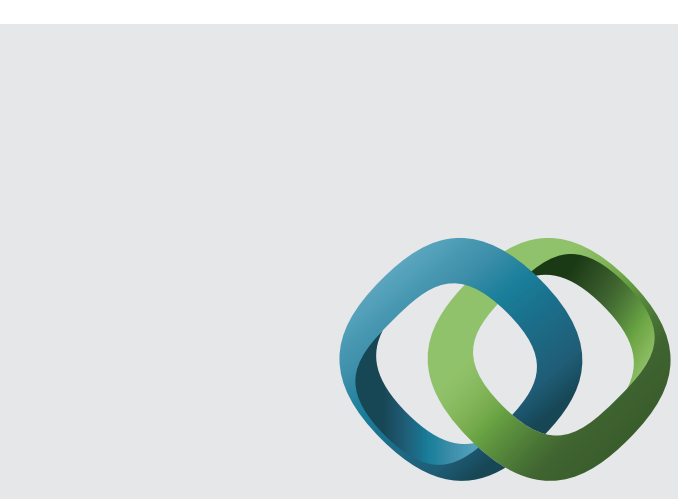

\section{Hindawi}

Submit your manuscripts at

http://www.hindawi.com
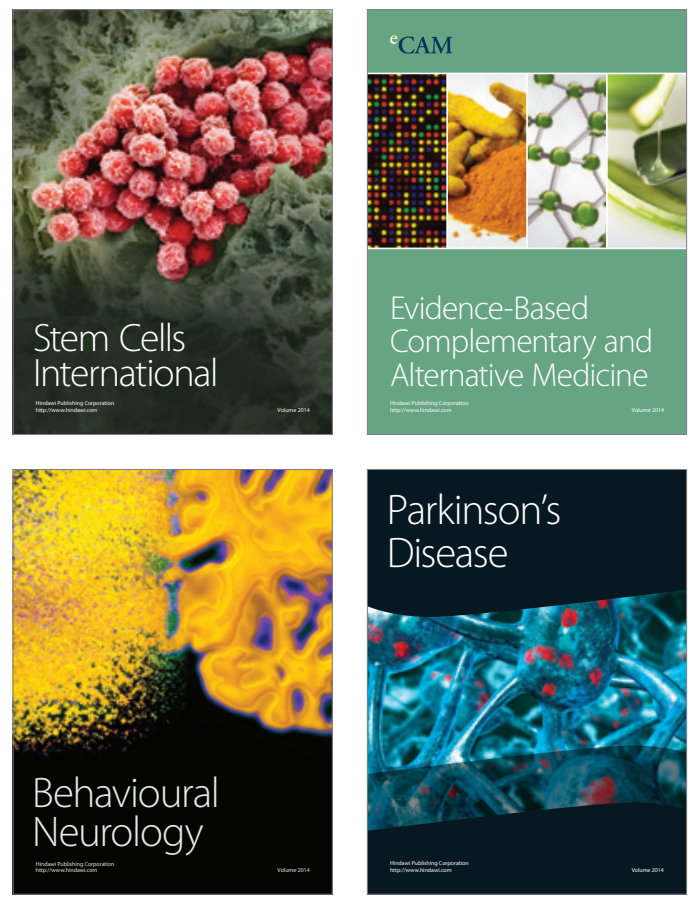
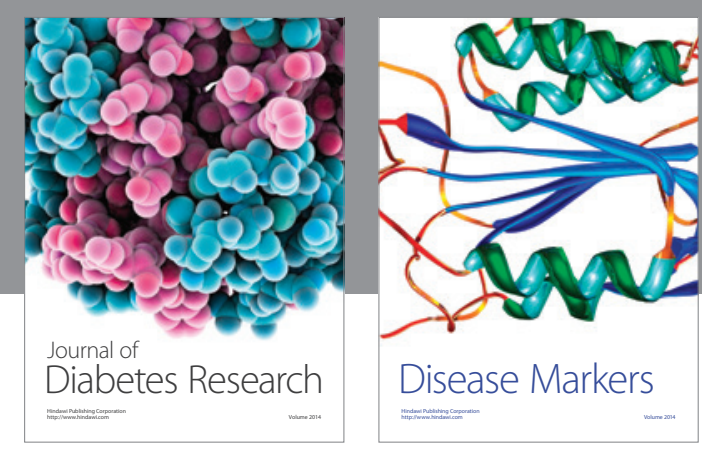

Disease Markers
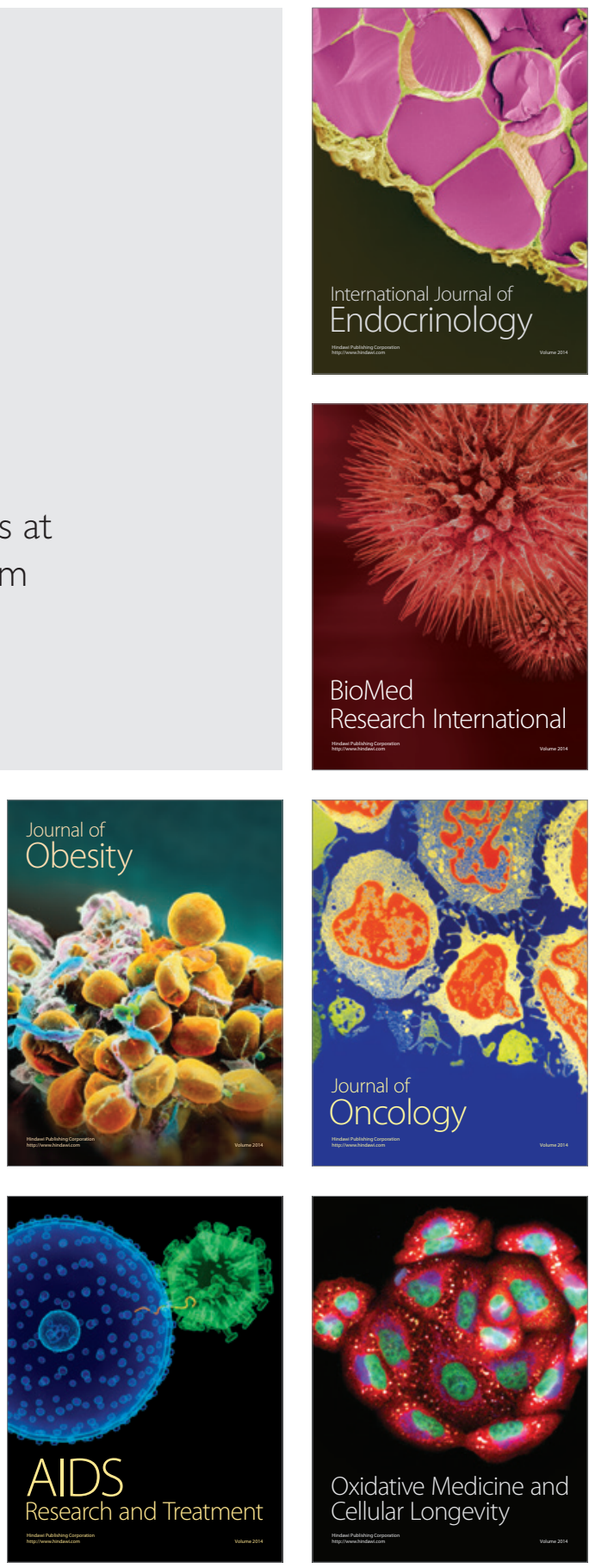